Grand Valley State University

ScholarWorks@GVSU

2014

\title{
Hand Pulling Following Mowing and Herbicide Treatments Increases Control of Spotted Knapweed (Centaurea stoebe)
}

Neil W. MacDonald

Grand Valley State University, macdonan@gvsu.edu

Laurelin M. Martin

Corey K. Kapolka

Timothy F. Botting

Tami E. Brown

Follow this and additional works at: https://scholarworks.gvsu.edu/oapsf_articles

\section{ScholarWorks Citation}

MacDonald, Neil W.; Martin, Laurelin M.; Kapolka, Corey K.; Botting, Timothy F.; and Brown, Tami E., "Hand Pulling Following Mowing and Herbicide Treatments Increases Control of Spotted Knapweed (Centaurea stoebe)" (2014). Funded Articles. 22.

https://scholarworks.gvsu.edu/oapsf_articles/22

This Article is brought to you for free and open access by the Open Access Publishing Support Fund at ScholarWorks@GVSU. It has been accepted for inclusion in Funded Articles by an authorized administrator of ScholarWorks@GVSU. For more information, please contact scholarworks@gvsu.edu. 


\section{Hand Pulling Following Mowing and Herbicide Treatments Increases Control of Spotted Knapweed (Centaurea stoebe)}

Neil W. MacDonald, Laurelin M. Martin, Corey K. Kapolka, Timothy F. Botting, and Tami E. Brown*

Extensive areas in the upper Midwest have been invaded by spotted knapweed, and effective management strategies are required to reestablish native plant communities. We examined effects of mowing, mowing plus clopyralid, or mowing plus glyphosate in factorial combination with hand pulling and burning on knapweed abundances on a knapweed-infested site in western Michigan. We applied mowing and herbicide treatments in summer 2008, and seeded all plots with native grasses and forbs in spring 2009. We conducted the knapweed pulling treatment from 2009 to 2012 in July. The prescribed burn was conducted in April 2012. By 2012, hand pulling reduced adult knapweed densities to $0.57 \pm 0.12 \mathrm{~m}^{-2}\left(0.053 \pm 0.011 \mathrm{ft}^{-2}\right)$ (mean $\pm \mathrm{SE}$ ), which was $5.8 \%$ of nonpulled treatments, juvenile densities to $0.29 \pm 0.07 \mathrm{~m}^{-2}$ ( $2.1 \%$ of nonpulled treatments), and seedling densities to $0.07 \pm 0.06 \mathrm{~m}^{-2}$ (2.6\% of nonpulled treatments). After $3 \mathrm{yr}$, hand pulling reduced seed bank densities to $68 \pm 26 \mathrm{~m}^{-2}$ as compared to $524 \pm 254 \mathrm{~m}^{-2}$ in nonpulled treatments and $369 \pm 66 \mathrm{~m}^{-2}$ in adjacent untreated areas of the study site. Without hand pulling, effects of mowing or mowing plus glyphosate were short-lived and allowed knapweed to rapidly resurge. In comparison, although a single mowing plus clopyralid treatment maintained significantly reduced densities of knapweed for 4 yr, by 2012 knapweed biomass in the nonpulled clopyralid treatment was approximately $60 \%$ of that in the other nonpulled treatments. Burning had minimal impacts on knapweed densities regardless of treatment combination, probably as a result of low fire intensity. Results demonstrated that persistent hand pulling used as a follow-up to single mowing or mowing plus herbicide treatments can be an effective practice for treating isolated spotted knapweed infestations or for removing small numbers of knapweed that survive herbicide applications.

Nomenclature: Clopyralid; glyphosate; spotted knapweed, Centaurea stoebe L.

Key words: Burning, mowing, native plants, restoration, weed control.

Spotted knapweed (Centaurea stoebe L.), an invasive perennial forb, has colonized degraded lands and remnant natural areas throughout the upper Midwest. Knapweed can displace desirable plants, reduce wildlife habitat, and contribute to increased surface runoff and soil erosion (Sheley et al. 1998). As a result of its deep taproot (DiTomaso 2000), prolific seed production (Schirman 1981), long viability of seeds in the soil (Davis et al. 1993), competitive nutrient uptake (Herron et al. 2001), chemical exudations that inhibit other plants (Hierro and Callaway

DOI: $10.1614 /$ IPSM-D-12-00063.1

* First, second, fourth, and fifth authors: Professor, Graduate Student, Graduate Student, and Undergraduate Student, Department of Biology, Grand Valley State University, Allendale, MI 49401; third author: Graduate Student, Department of Environmental and Plant Biology, Ohio University, Athens, $\mathrm{OH} 45701$. Corresponding author’s E-mail: macdonan@gvsu.edu
2003), and activity of mycorrhizal fungi that can favor knapweed over native species (Carey et al. 2004), knapweed can form persistent infestations on droughty, degraded, and disturbed sites. On severely infested sites, knapweed typically is left uncontrolled or is controlled with herbicides (e.g., Duncan et al. 2011; Rice et al. 1997; Sheley et al. 2000), but herbicide use can inhibit the establishment or persistence of sensitive native species (Crone et al. 2009; Rinella et al. 2009; Skurski et al. 2013; Tyser et al. 1998).

Recent work suggests that reestablishing a diverse native plant community can provide increased resistance to reinvasion by knapweed (Maron and Marler 2007; Sheley and Half 2006). Active management to suppress knapweed while native species are establishing can be required (Carpinelli et al. 2004), and treatments such as mowing (Rinella et al. 2001; Watson and Renney 1974), hand pulling (Abella 2001; Sheley et al. 1998), or burning 


\section{Management Implications}

We studied the interactive effects of mowing, herbicides, hand pulling, and burning on spotted knapweed control in western Michigan. Effects of a single mowing or mowing plus glyphosate on spotted knapweed were short-lived. In contrast, a single application of mowing plus clopyralid maintained reduced knapweed densities for $4 \mathrm{yr}$ after treatment. In the fourth year, however, knapweed biomass in the nonpulled mowed plus clopyralid treatment was approximately $60 \%$ of the other nonpulled treatments, evidence that knapweed was resurging in the clopyralid treatment as well. Contrary to expectations, there were minimal effects of a single spring burn on spotted knapweed densities, probably as a result of suboptimal season of burn and cool burn-day temperatures, which caused low fire intensity. In comparison to other treatments, hand pulling more effectively controlled all knapweed life stages after 3 yr of treatment. Initially, hand-pulling removals were greatest on mowed-only plots $\left(44 \pm 7 \mathrm{~m}^{-2}\right.$, mean $\left.\pm \mathrm{SE}\right)$, increased in both clopyralid and glyphosate-treated plots in the second year as knapweed populations began to recover from herbicides, and then equalized at greatly reduced levels $\left(0.6 \pm 0.1 \mathrm{~m}^{-2}\right)$ across all mowing and herbicide treatments by the fourth year. Removing knapweed by hand requires a large investment of time, however, and this must be taken into account when planning strategies for restoring knapweed-infested sites. To be effective, hand pulling needs to be applied persistently in advance of seed dispersal over several years. Hand pulling can be an effective practice for treating relatively small knapweed infestations in areas being restored to native vegetation, or as a follow-up treatment after herbicides have been used to reduce large infestations. Hand pulling also provides a treatment option in natural areas where herbicides are restricted to prevent damage to native plants.

(Emery and Gross 2005; MacDonald et al. 2007; Vermeire and Rinella 2009) can be incorporated into an integrated strategy to control knapweed. Although hand pulling has been reported to provide effective control of spotted knapweed and other Centaurea species (DiTomaso 2000; Hastings and DiTomaso 1996; Sheley et al. 1998), published supporting data are rare. For example, in one of the few published studies that included hand pulling as a knapweed management method, Lutgen and Rillig (2004) reported that treatment with picloram combined with annual hand pulling reduced spotted knapweed cover to very low levels. In this same study, however, $4 \mathrm{yr}$ of hand pulling alone did not reduce spotted knapweed cover below that of an untreated control, possibly because only the top 2.5 to $5 \mathrm{~cm}$ (1 to 2 in) of root were removed along with aboveground portions of the plants (Brown et al. 1999). In comparison, Skurski et al. (2013) found that a single hand pulling reduced knapweed cover from $10 \%$ to less than $2 \%$ after $1 \mathrm{yr}$, but knapweed cover then began to increase in the absence of further treatment. Ultimately, all knapweed life stages including adults, juveniles, seedlings, and the soil seed bank must be controlled when restoring an infested site, because populations can rebound from these life stages even if all adults are initially eliminated by single herbicide or hand-pulling treatments (Duncan et al. 2011; Sheley et al. 1998; Story et al. 2008).

The native plant community at our study location was removed and surface soils heavily disturbed by agricultural conversion and gravel mining in the early to mid-1900s, leaving a persistent ruderal plant community infested by spotted knapweed (MacDonald et al. 2003, 2007). We examined combinations of herbicide treatments and mechanical management methods as components of a strategy to control spotted knapweed. Mowing can be used to reduce competition and seed dispersal from nonnatives prior to interseeding with desired native species, or as an initial site preparation treatment in advance of herbicide applications (Packard and Mutel 1997). Clopyralid is a broadleaf herbicide that can control spotted knapweed while favoring grasses, but it kills many native forbs through foliar contact and its residual soil effects can inhibit establishment of certain native forbs, especially legumes (Rice et al. 1997; Tyser et al. 1998). Glyphosate is a broad-spectrum herbicide that has no residual soil activity, but it can allow more rapid resurgence of spotted knapweed from the seed bank (MacDonald et al. 2003; Sheley et al. 2001). Hand pulling of adult knapweed has promise as a follow-up control measure to herbicide treatments (Brown et al. 1999; Lutgen and Rillig 2004; Skurski et al. 2013), but also can be very labor intensive. Burning can help control spotted knapweed by reducing seed germination, plant survival, and/or flowering, but it requires both optimal timing and sufficient fuel loads to consistently achieve these results (Emery and Gross 2005; MacDonald et al. 2007; Vermeire and Rinella 2009).

The objective of our study was to determine the responses of knapweed to treatment combinations that included mowing, herbicides, annual hand pulling, and burning. Based on previous research, including a study conducted in an adjacent area at the same study location (MacDonald et al. 2003, 2007), we hypothesized that a single mowing plus herbicide application would more effectively control adult knapweed than a single mowing alone, and that clopyralid would provide longer-lasting control than glyphosate. We hypothesized that hand pulling would reduce knapweed seed production and thereby provide effective control of all life stages of knapweed through time. Finally, we hypothesized that burning would provide additional control of all life stages of knapweed.

\section{Materials and Methods}

Experimental Design. The study was conducted within the Bass River Recreation Area (Sect. 12, T7N R15W, Ottawa County, Michigan; $\left.43^{\circ} 00^{\prime} 49^{\prime \prime} \mathrm{N}, 86^{\circ} 01^{\prime} 47^{\prime \prime} \mathrm{W}\right)$. In July 2008 we established the field experiment using a 
randomized complete block design with a factorial arrangement of 12 treatment combinations and four replicate blocks for a total of 48, 5- by 5-m (16.4- by 16.4-ft) plots. The 12 treatment combinations consisted of three one-time applications of mowing, mowing plus clopyralid, or mowing plus glyphosate; each combined with or without hand pulling and with or without burning. The mowing and herbicide treatments completed in 2008 included a single mowing in mid-July, alone and in combination with either clopyralid (Transline ${ }^{\circledR}$; Dow AgroSciences, Indianapolis, IN) at $0.6 \mathrm{~kg} \mathrm{ae} \mathrm{ha}{ }^{-1}\left(0.5 \mathrm{lb}\right.$ ae ac$\left.{ }^{-1}\right)$ in mid-August or glyphosate (Roundup Concentrate Plus ${ }^{\circledR}$; Monsanto, Marysville, $\mathrm{OH}$ ) at $9.9 \mathrm{~kg}$ ae ha ${ }^{-1}$ in early September. Hereafter, the mowing plus herbicide treatments will be referred to as either clopyralid or glyphosate treatments for brevity. We included 5-m buffers around each block and $2.5-\mathrm{m}$ buffers between plots and mowed the buffers once each year in late June. In mid-May 2009, we seeded all plots at a rate of $22 \mathrm{~kg} \mathrm{ha}^{-1}$ with a diverse native seed mix containing $60 \%$ grasses and $40 \%$ forbs (sandy mix; Michigan Wildflower Farm, Portland, MI). The seed mix approximated the species composition of southern Michigan dry sand prairies, dry-mesic prairies, and oak barrens, consistent with our restoration goals for this heavily disturbed site (MacDonald et al. 2007).

Hand-Pulling Treatment. We conducted the handpulling treatment prior to seed maturation and dispersal each year from 2009 to 2012. In early July and again in mid-July, we counted and removed bolted plants using a fork-tipped hand weeder (Ergonomic Hand Weeder, Item \#2306; Shanghai Worth Garden Products Co., Ltd., Shanghai, China), making sure to extract the entire tap root. We separated roots from shoots, and dried $(70 \mathrm{C}$ [158 F], $48 \mathrm{~h}$ ) and weighed the aboveground knapweed biomass.

Burning Treatment. The burning treatment occurred on April 2, 2012, between 1 and 4 P.M. Mean burn-day air temperature was $13.7 \mathrm{C}$ with $49 \%$ mean relative humidity. Each plot was ignited using a drip torch, beginning at the downwind side and proceeding along all four sides of the plot. Vegetation on most plots burned completely after ignition, but some plots required additional ignition to burn remaining fuels. To provide an index of relative flame temperature and duration, we placed one $7.6-$ by $15.2-\mathrm{cm}$ (3- by 6-in) ceramic tile pyrometer in each plot quarter (four per plot). Each tile was painted with stripes of 14 different lacquers designed to melt at specific temperatures ranging from $79 \mathrm{C}$ to $316 \mathrm{C}$ (Kennard et al. 2005; Wally et al. 2006). Mean pyrometer temperatures recorded at ground level on individual plots ranged from $<79 \mathrm{C}$ to $159 \mathrm{C}$ during the burn treatment.
Soil Characterization. In early May 2009, we sampled the upper $15 \mathrm{~cm}$ of soil on each plot using an 8-cm-diam bucket auger. Four samples were taken systematically on each plot, one at the center of each plot quarter. Samples were composited by plot, air-dried, and passed through a $2-\mathrm{mm}(0.08$-in) sieve prior to analysis. We analyzed all samples for $\mathrm{pH}$, organic carbon, coarse fragments, and texture using standard soil analytical procedures (Klute 1986; Page et al. 1982). Soils at the study site were sands to loamy sands $(87 \pm 3 \%$ sand, mean $\pm \mathrm{SD})$ that were slightly alkaline $(\mathrm{pH} 7.8 \pm 0.5)$, low in organic carbon $(0.9 \pm 0.3 \%)$, and contained variable amounts of gravel $(18 \pm 10 \%)$. Previous investigations (MacDonald et al. 2003) suggest that pre-disturbance soils were Plainfield sands (mixed, mesic, Typic Udipsamments).

Vegetation Evaluation. We sampled knapweed seedling (one to four primary leaves), juvenile (unbolted rosettes), and adult (bolted) densities in mid-July each year from 2009 to 2012. We counted all knapweed by life stage in five randomly located 50 - by $50-\mathrm{cm}$ frames on each plot. On nonpulled plots, adult knapweed plants within the frames were counted, clipped at ground level, dried $(70 \mathrm{C}, 48 \mathrm{~h}$ ), and weighed to estimate aboveground biomass. On handpulled plots, adult knapweed densities and biomass were determined at the time of hand-pulling in early and midJuly, as opposed to mid-July in nonpulled plots. Adult knapweed data for hand-pulled plots reported in this paper represent the totals removed by hand pulling in both early and mid-July. Because adult knapweed densities do not fluctuate greatly in mid-summer, adult knapweed densities were directly comparable between hand-pulled and nonpulled plots. Conversely, because knapweed actively grows throughout July, measuring biomass in early July in pulled plots and mid-July in nonpulled plots likely caused slight underestimates of effects of pulling on knapweed biomass.

In mid- to late March from 2009 to 2012, before spring germination of knapweed, we collected five seed bank samples in a systematic grid pattern from the upper $5 \mathrm{~cm}$ of soil of each plot using a 4.5 -cm-diam metal corer. We also collected seed bank samples from 16, 5- by 5-m plots (four plots per block) in areas adjacent to the study site to provide an untreated control. We spread composited seed bank/soil samples approximately $2.5 \mathrm{~cm}$ deep on top of sterile potting soil in $12.7-\mathrm{cm}$ tall, $15-\mathrm{cm}$-diam plastic pots. We arranged the pots in a greenhouse in a randomized complete block design. The greenhouse was maintained between $18 \mathrm{C}$ and $29 \mathrm{C}$ without supplemental lighting, and the pots were watered as needed to keep soils adequately moist. Germinated knapweed seedlings were counted and removed at least once a week from late March through mid-June. To encourage germination, we stirred the soils approximately once every 3 wk.

In 2009 and 2010, we recorded the presence/absence of each grass and forb species in the seed mix on the same five 
frames used to estimate knapweed densities. In 2011 and 2012, we visually estimated percent cover of each grass and forb species in each plot, determining a plot estimate by averaging one cover estimate from each of the four quarters of the plot.

Statistical Analysis of Plant Data. We tested for homogeneity of variance using Bartlett's test (Steel and Torrie 1980), and also examined preliminary parametric ANOVA residuals for constant variance among treatment combinations. We examined normal probability plots of preliminary parametric ANOVA residuals, and tested the residuals for normality with Lilliefor's test (Wilkinson 1989). Adult knapweed density and biomass, juvenile and seedling knapweed density, knapweed seed bank, native grass and forb presence, and native grass and forb percent cover data did not meet assumptions of equality of variance and normality, so we used nonparametric permutational factorial analyses of variance (PERMANOVA: Anderson 2005; McArdle and Anderson 2001) to test for treatment effects for these variables. These analyses of variance were based on Bray-Curtis dissimilarities for knapweed density and on Euclidean distances for knapweed biomass, native grass and forb presence, and native grass and forb percent cover (McArdle and Anderson 2001). P values were based on unrestricted permutation of raw data using 4,999 permutations for each analysis. For data collected from 2009 through 2011, we included the three mowing and herbicide treatments and two hand-pulling levels as factors in two-way analyses of variance. In 2012, we included the two burning levels as an additional factor in three-way analyses of variance. Exploratory analyses suggested block effects were small and including block terms in the model would not greatly alter results, so we pooled block effects with error terms in the PERMANOVA. PERMANOVA is not designed to allow a repeated measures analysis of variance, so we ran separate analyses for each year. We concluded significance for all statistical analyses at $\mathrm{P}<0.05$, and used pairwise comparisons within PERMANOVA to identify differences among treatments where main or interaction effects were significant.

\section{Results and Discussion}

Native Grasses and Forbs. Averaged across all treatment combinations, in $2010,33 \%$ of $0.25-\mathrm{m}^{2}$ frames sampled had at least one seeded native grass species present and $17.5 \%$ of frames had at least one seeded native forb species present. The percent occurrence of native grasses and forbs did not differ significantly among treatment combinations. Similarly, average percent cover of native grasses was $11.9 \%$ in 2011 and $15.1 \%$ in 2012, and did not differ significantly among treatment combinations. Although the main effect of pulling on forb cover was significant, native forb percent cover was only $3.9 \%$ on nonpulled plots and $6.9 \%$ on pulled plots in 2012. It is likely the seeded species competed somewhat with knapweed (Rinella et al. 2007), but we did not detect any differences in knapweed density or biomass that were related to variation in native grass and forb cover.

Mowing and Herbicide Effects on Knapweed. Adult knapweed densities differed significantly among all mowing and herbicide treatments in 2009, with clopyralid providing good control of adult knapweed (Table 1). By 2012, differences between nonpulled mowed and nonpulled glyphosate treatments were no longer significant, but a single treatment with clopyralid maintained lower densities of adult knapweed. In 2009, patterns in adult knapweed biomass were similar to those of adult knapweed densities, being greatest on the mowed treatments that excluded herbicides and least on the clopyralid treatments (Table 2). By 2012, however, biomass did not differ significantly among the nonpulled mowing and herbicide treatments.

As compared to higher seedling densities measured in the nonpulled mowed treatment in 2010 and 2011, knapweed seedlings were present in relatively low densities on all treatment combinations in 2009 (Table 3). This was probably a combined effect of reduced seed fall resulting from mowing and herbicide treatments in 2008 and belownormal rainfall during May and July in 2009 (NCDC 2009). Similar to its effects on adult knapweed, a single application of clopyralid on the nonpulled treatments maintained lower seedling and juvenile densities for $4 \mathrm{yr}$ as compared to one or both of the mowed or glyphosate treatments (Tables 3, 4).

Other than reducing seed production for $1 \mathrm{yr}$ (Watson and Renney 1974), a single mowing in the late bud/early flowering stage had few effects on knapweed in our study. Total knapweed density had increased from $100 \pm 19$ (mean \pm SE) in 2009 to $251 \pm 47 \mathrm{~m}^{-2}$ in 2010 on nonpulled mowed plots, and remained at a comparable level in $2011\left(218 \pm 38 \mathrm{~m}^{-2}\right)$. These values resemble total knapweed densities in untreated areas of the study site measured in $1999\left(239 \pm 16 \mathrm{~m}^{-2}\right.$; N. W. MacDonald, unpublished data), suggesting that knapweed populations quickly recovered to pretreatment levels on the nonpulled mowed plots. As with our study, Kennett et al. (1992) found that a single defoliation during the bolted stage had minimal impacts on knapweed growth or survival. Conversely, Rinella et al. (2001) found that postbolting mowings applied for $3 \mathrm{yr}$ reduced adult knapweed densities by greater than $80 \%$. These observations suggest that annual mowings might need to be continued for several years to control adult knapweed densities, decrease seed production, and reduce the knapweed seed bank before attempting to establish native species on a knapweedinfested site. 
Table 1. Adult knapweed density (mean $\pm \mathrm{SE}$ ) at the Bass River Recreation Area, Ottawa County, Michigan, as affected by initial mowing and herbicide treatments or hand pulling. Means followed by different letters differ significantly.

\begin{tabular}{|c|c|c|c|c|c|}
\hline \multirow[b]{2}{*}{ Year } & \multirow[b]{2}{*}{$\begin{array}{l}\text { Hand-pulling } \\
\text { treatment }\end{array}$} & \multicolumn{3}{|c|}{ Initial mowing or herbicide treatment } & \multirow[b]{2}{*}{$\begin{array}{c}\text { Hand-pulling } \\
\text { means }\end{array}$} \\
\hline & & Mowing & $\begin{array}{l}\text { Mowing plus } \\
\text { clopyralid }\end{array}$ & $\begin{array}{l}\text { Mowing plus } \\
\text { glyphosate }\end{array}$ & \\
\hline & & & -plan & $n^{-2}$ & \\
\hline \multirow[t]{3}{*}{2009} & Nonpulled & $47.0 \pm 7.1$ & $0.0 \pm 0.0$ & $2.5 \pm 1.0$ & $16.5 \pm 5.1$ \\
\hline & Pulled & $44.2 \pm 6.6$ & $0.0 \pm 0.0$ & $3.1 \pm 0.8$ & $15.8 \pm 4.7$ \\
\hline & MH means & $45.6 \pm 4.7 \mathrm{~m}^{\mathrm{a}}$ & $0.0 \pm 0.0 \mathrm{o}$ & $2.8 \pm 0.6 \mathrm{n}$ & \\
\hline \multirow[t]{3}{*}{2010} & Nonpulled & $71.6 \pm 10.7 \mathrm{a}, \mathrm{x}$ & $1.5 \pm 0.5 \mathrm{c}$ & $23.6 \pm 5.7 b$ & $32.2 \pm 7.2 \times$ \\
\hline & Pulled & $16.9 \pm 3.4 \mathrm{a}, \mathrm{y}$ & $3.3 \pm 0.9 \mathrm{~b}$ & $27.1 \pm 7.5 \mathrm{a}$ & $15.8 \pm 3.3 y$ \\
\hline & MH means & $44.3 \pm 8.9 \mathrm{~m}$ & $2.4 \pm 0.6 \mathrm{n}$ & $25.3 \pm 4.6 \mathrm{~m}$ & \\
\hline \multirow[t]{3}{*}{2011} & Nonpulled & $69.8 \pm 6.6 \mathrm{a}, \mathrm{x}$ & $3.2 \pm 0.9 \mathrm{c}$ & $25.6 \pm 5.7 \mathrm{~b}, \mathrm{x}$ & $32.9 \pm 6.4 x$ \\
\hline & Pulled & $5.8 \pm 1.5 \mathrm{a}, \mathrm{y}$ & $2.2 \pm 0.5 \mathrm{~b}$ & $10.4 \pm 2.3 \mathrm{a}, \mathrm{y}$ & $6.1 \pm 1.1 \mathrm{y}$ \\
\hline & MH means & $37.8 \pm 8.9 \mathrm{~m}$ & $2.7 \pm 0.5 \mathrm{n}$ & $18.0 \pm 3.6 \mathrm{~m}$ & \\
\hline \multirow[t]{3}{*}{2012} & Nonpulled & $13.5 \pm 2.5 \mathrm{a}, \mathrm{x}$ & $3.1 \pm 1.1 \mathrm{~b}, \mathrm{x}$ & $12.8 \pm 2.3 \mathrm{a}, \mathrm{x}$ & $9.8 \pm 1.5 \mathrm{x}$ \\
\hline & Pulled & $0.63 \pm 0.19 \mathrm{ab}, \mathrm{y}$ & $0.20 \pm 0.05 \mathrm{~b}, \mathrm{y}$ & $0.88 \pm 0.26 \mathrm{a}, \mathrm{y}$ & $0.57 \pm 0.12 y$ \\
\hline & MH means & $7.1 \pm 2.1$ & $1.6 \pm 0.6$ & $6.8 \pm 1.9$ & \\
\hline
\end{tabular}

${ }^{a}$ Letters a, b, and c compare mowing or herbicide means within a single year and hand-pulling treatment; $\mathrm{m}, \mathrm{n}$, and o compare mowing or herbicide main effects means (MH means) within a single year; and $\mathrm{x}$ and $\mathrm{y}$ compare hand-pulling means within a single year and mowing or herbicide treatment, or compare hand-pulling main effects means within a single year. If interaction effects were not significant, lettering is only shown for significant main effects.

Table 2. Adult knapweed aboveground biomass (mean \pm SE) at the Bass River Recreation Area, Ottawa County, Michigan, as affected by initial mowing and herbicide treatments or hand pulling. Means followed by different letters differ significantly.

\begin{tabular}{|c|c|c|c|c|c|}
\hline \multirow[b]{2}{*}{ Year } & \multirow[b]{2}{*}{$\begin{array}{c}\text { Hand-pulling } \\
\text { treatment }\end{array}$} & \multicolumn{3}{|c|}{ Initial mowing or herbicide treatment } & \multirow[b]{2}{*}{$\begin{array}{l}\text { Hand-pulling } \\
\text { means }\end{array}$} \\
\hline & & Mowing & $\begin{array}{l}\text { Mowing plus } \\
\text { clopyralid }\end{array}$ & $\begin{array}{l}\text { Mowing plus } \\
\text { glyphosate }\end{array}$ & \\
\hline & & & & -2 & \\
\hline \multirow[t]{3}{*}{2009} & Nonpulled & $142.2 \pm 25.7 \mathrm{a}, \mathrm{x}^{\mathrm{a}}$ & $0.0 \pm 0.0 \mathrm{c}$ & $8.1 \pm 2.6 \mathrm{~b}$ & $50.1 \pm 15.9 x$ \\
\hline & Pulled & $78.8 \pm 7.0 \mathrm{a}, \mathrm{y}$ & $0.0 \pm 0.0 \mathrm{c}$ & $5.8 \pm 1.4 \mathrm{~b}$ & $28.2 \pm 7.8 y$ \\
\hline & MH means & $110.5 \pm 15.3 \mathrm{~m}$ & $0.0 \pm 0.0 \mathrm{o}$ & $7.0 \pm 1.4 \mathrm{n}$ & \\
\hline \multirow[t]{3}{*}{2010} & Nonpulled & $126.4 \pm 19.1 \mathrm{a}, \mathrm{x}$ & $7.8 \pm 3.3 \mathrm{~b}$ & $81.3 \pm 15.7 \mathrm{a}$ & $71.8 \pm 12.9 \mathrm{x}$ \\
\hline & Pulled & $46.9 \pm 8.1$ a, $y$ & $21.9 \pm 6.5 \mathrm{~b}$ & $60.3 \pm 12.2 \mathrm{a}$ & $43.0 \pm 6.1 \mathrm{y}$ \\
\hline & MH means & $86.6 \pm 14.3 \mathrm{~m}$ & $14.9 \pm 4.0 \mathrm{n}$ & $70.8 \pm 10.0 \mathrm{~m}$ & \\
\hline \multirow[t]{3}{*}{2011} & Nonpulled & $135.9 \pm 21.0 \mathrm{a}, \mathrm{x}$ & $44.3 \pm 10.5 \mathrm{~b}, \mathrm{x}$ & $140.7 \pm 14.4 \mathrm{a}, \mathrm{x}$ & $106.9 \pm 12.8 \mathrm{x}$ \\
\hline & Pulled & $24.9 \pm 7.4 y$ & $16.2 \pm 4.7 y$ & $31.1 \pm 6.1 \mathrm{y}$ & $24.1 \pm 3.6 y$ \\
\hline & MH means & $80.4 \pm 17.9 \mathrm{~m}$ & $30.2 \pm 6.7 \mathrm{n}$ & $85.9 \pm 16.0 \mathrm{~m}$ & \\
\hline \multirow[t]{3}{*}{2012} & Nonpulled & $40.3 \pm 8.8$ & $27.2 \pm 15.0$ & $48.4 \pm 13.6$ & $38.6 \pm 7.3 x$ \\
\hline & Pulled & $3.8 \pm 1.5$ & $1.3 \pm 0.4$ & $3.1 \pm 0.8$ & $2.7 \pm 0.6 y$ \\
\hline & MH means & $22.0 \pm 6.4$ & $14.2 \pm 8.0$ & $25.8 \pm 8.8$ & \\
\hline
\end{tabular}

${ }^{a}$ Letters $\mathrm{a}, \mathrm{b}$, and c compare mowing or herbicide means within a single year and hand pulling treatment; $\mathrm{m}, \mathrm{n}$, and o compare mowing or herbicide main effects means ( $\mathrm{MH}$ means) within a single year; and $\mathrm{x}$ and $\mathrm{y}$ compare hand-pulling means within a single year and mowing or herbicide treatment, or compare hand-pulling main effects means within a single year. If interaction effects were not significant, lettering is only shown for significant main effects. 
Table 3. Seedling knapweed density (mean \pm SE) at the Bass River Recreation Area, Ottawa County, Michigan, as affected by initial mowing and herbicide treatments or hand pulling. Means followed by different letters differ significantly.

\begin{tabular}{|c|c|c|c|c|c|}
\hline \multirow[b]{2}{*}{ Year } & \multirow[b]{2}{*}{$\begin{array}{l}\text { Hand-pulling } \\
\text { treatment }\end{array}$} & \multicolumn{3}{|c|}{ Initial mowing or herbicide treatment } & \multirow[b]{2}{*}{$\begin{array}{c}\text { Hand-pulling } \\
\text { means }\end{array}$} \\
\hline & & Mowing & $\begin{array}{l}\text { Mowing plus } \\
\text { clopyralid }\end{array}$ & $\begin{array}{l}\text { Mowing plus } \\
\text { glyphosate }\end{array}$ & \\
\hline & & & -plar & $m^{-2}$ & \\
\hline \multirow[t]{3}{*}{2009} & Nonpulled & $13.4 \pm 4.0$ & $1.3 \pm 0.4$ & $8.0 \pm 3.4$ & $7.6 \pm 2.0 \mathrm{x}$ \\
\hline & Pulled & $4.7 \pm 1.1$ & $2.7 \pm 0.5$ & $7.3 \pm 1.5$ & $4.9 \pm 0.7 \mathrm{y}$ \\
\hline & MH means & $9.1 \pm 2.3 \mathrm{~m}^{\mathrm{a}}$ & $2.0 \pm 0.4 \mathrm{n}$ & $7.7 \pm 1.8 \mathrm{~m}$ & \\
\hline \multirow[t]{3}{*}{2010} & Nonpulled & $121.6 \pm 29.9 a, x$ & $1.7 \pm 0.6 \mathrm{~b}$ & $3.4 \pm 1.4 \mathrm{~b}$ & $42.2 \pm 15.1 \mathrm{x}$ \\
\hline & Pulled & $3.9 \pm 1.3 \mathrm{y}$ & $2.3 \pm 0.4$ & $2.3 \pm 0.8$ & $2.8 \pm 0.5 \mathrm{y}$ \\
\hline & MH means & $62.8 \pm 21.0 \mathrm{~m}$ & $2.0 \pm 0.3 \mathrm{n}$ & $2.8 \pm 0.8 \mathrm{n}$ & \\
\hline \multirow[t]{3}{*}{2011} & Nonpulled & $109.9 \pm 30.6 \mathrm{a}, \mathrm{x}$ & $5.7 \pm 3.0 \mathrm{~b}, \mathrm{x}$ & $162.1 \pm 65.0 \mathrm{a}, \mathrm{x}$ & $92.6 \pm 26.6 x$ \\
\hline & Pulled & $0.9 \pm 0.3 \mathrm{ab}, \mathrm{y}$ & $0.4 \pm 0.2 \mathrm{~b}, \mathrm{y}$ & $2.2 \pm 0.5 \mathrm{a}, \mathrm{y}$ & $1.2 \pm 0.3 \mathrm{y}$ \\
\hline & MH means & $55.4 \pm 20.4 \mathrm{mn}$ & $3.1 \pm 1.6 \mathrm{n}$ & $82.2 \pm 37.6 \mathrm{~m}$ & \\
\hline \multirow[t]{3}{*}{2012} & Nonpulled & $3.0 \pm 1.2 \mathrm{ab}$ & $0.11 \pm 0.10 \mathrm{~b}$ & $4.8 \pm 1.5 \mathrm{a}, \mathrm{x}$ & $2.6 \pm 0.7 x$ \\
\hline & Pulled & $0.19 \pm 0.18$ & $0.02 \pm 0.01$ & $0.0 \pm 0.0 \mathrm{y}$ & $0.07 \pm 0.06 \mathrm{y}$ \\
\hline & MH means & $1.6 \pm 0.7$ & $0.06 \pm 0.05$ & $2.4 \pm 0.9$ & \\
\hline
\end{tabular}

${ }^{a}$ Letters a, b, and c compare mowing or herbicide means within a single year and hand-pulling treatment; $\mathrm{m}$ and $\mathrm{n}$ compare mowing or herbicide main effects means (MH means) within a single year; and $\mathrm{x}$ and $\mathrm{y}$ compare hand-pulling means within a single year and mowing or herbicide treatment, or compare hand-pulling main effects means within a single year. If interaction effects were not significant, lettering is only shown for significant main effects.

Table 4. Juvenile knapweed density (mean \pm SE) at the Bass River Recreation Area, Ottawa County, Michigan, as affected by initial mowing and herbicide treatments or hand pulling. Means followed by different letters differ significantly.

\begin{tabular}{|c|c|c|c|c|c|}
\hline \multirow[b]{2}{*}{ Year } & \multirow[b]{2}{*}{$\begin{array}{l}\text { Hand-pulling } \\
\text { treatment }\end{array}$} & \multicolumn{3}{|c|}{ Initial mowing or herbicide treatment $(\mathrm{MH})$} & \multirow[b]{2}{*}{$\begin{array}{c}\text { Hand-pulling } \\
\text { means }\end{array}$} \\
\hline & & Mowing & $\begin{array}{l}\text { Mowing plus } \\
\text { clopyralid }\end{array}$ & $\begin{array}{l}\text { Mowing plus } \\
\text { glyphosate }\end{array}$ & \\
\hline & & & -plan & $n^{-2}$ & \\
\hline \multirow{3}{*}{2009} & Nonpulled & $39.7 \pm 9.3$ & $2.9 \pm 1.2$ & $37.1 \pm 11.1$ & $26.6 \pm 5.8$ \\
\hline & Pulled & $23.5 \pm 3.2$ & $3.0 \pm 0.9$ & $49.8 \pm 12.9$ & $25.4 \pm 5.8$ \\
\hline & MH means & $31.6 \pm 5.2 \mathrm{~m}^{\mathrm{a}}$ & $3.0 \pm 0.7 \mathrm{n}$ & $43.5 \pm 8.4 \mathrm{~m}$ & \\
\hline \multirow[t]{3}{*}{2010} & Nonpulled & $57.4 \pm 11.6 \mathrm{a}, \mathrm{x}$ & $1.6 \pm 0.6 \mathrm{c}$ & $10.7 \pm 2.4 \mathrm{~b}$ & $23.2 \pm 6.3 x$ \\
\hline & Pulled & $6.7 \pm 1.1 \mathrm{a}, \mathrm{y}$ & $2.0 \pm 0.5 \mathrm{~b}$ & $12.3 \pm 5.1 \mathrm{a}$ & $7.0 \pm 1.9 y$ \\
\hline & MH means & $32.1 \pm 8.6 \mathrm{~m}$ & $1.8 \pm 0.4 \mathrm{n}$ & $11.5 \pm 2.7 \mathrm{~m}$ & \\
\hline \multirow[t]{3}{*}{2011} & Nonpulled & $38.2 \pm 4.1 \mathrm{a}, \mathrm{x}$ & $1.4 \pm 0.6 \mathrm{c}$ & $8.4 \pm 1.7 \mathrm{~b}, \mathrm{x}$ & $16.0 \pm 3.6 x$ \\
\hline & Pulled & $0.8 \pm 0.3 \mathrm{ab}, \mathrm{y}$ & $0.4 \pm 0.2 \mathrm{~b}$ & $2.9 \pm 0.8$ a, $y$ & $1.4 \pm 0.3 \mathrm{y}$ \\
\hline & MH means & $19.5 \pm 5.2 \mathrm{~m}$ & $0.9 \pm 0.3$ o & $5.7 \pm 1.1 \mathrm{n}$ & \\
\hline \multirow[t]{3}{*}{2012} & Nonpulled & $18.1 \pm 4.1 \mathrm{a}, \mathrm{x}$ & $1.6 \pm 0.6 \mathrm{~b}, \mathrm{x}$ & $20.7 \pm 8.2 \mathrm{a}, \mathrm{x}$ & $13.5 \pm 3.4 x$ \\
\hline & Pulled & $0.28 \pm 0.05$ a, $y$ & $0.06 \pm 0.03 \mathrm{~b}, \mathrm{y}$ & $0.53 \pm 0.16 \mathrm{a}, \mathrm{y}$ & $0.29 \pm 0.07 \mathrm{y}$ \\
\hline & MH means & $9.2 \pm 3.0 \mathrm{~m}$ & $0.8 \pm 0.5 \mathrm{n}$ & $10.6 \pm 4.7 \mathrm{~m}$ & \\
\hline
\end{tabular}

${ }^{a}$ Letters a, b, and c compare mowing or herbicide means within a single year and hand-pulling treatment; $\mathrm{m}, \mathrm{n}$, and o compare mowing or herbicide main effects means (MH means) within a single year; and $\mathrm{x}$ and $\mathrm{y}$ compare hand-pulling means within a single year and mowing or herbicide treatment, or compare hand-pulling main effects means within a single year. If interaction effects were not significant, lettering is only shown for significant main effects. 
Similar to other studies, single treatments with either clopyralid or glyphosate initially were effective in reducing adult spotted knapweed densities (Rice et al. 1997; Sheley et al. 2000, 2001). Clopyralid maintained reduced knapweed densities for $4 \mathrm{yr}$, but glyphosate had much less persistent impacts. These results are consistent with previous reports that the effect of glyphosate on suppressing spotted knapweed was less long-lived than that of clopyralid (Sheley et al. 2001). Adult knapweed density in the nonpulled clopyralid treatment remained fairly low in 2011 and 2012, but adult knapweed biomass in this treatment did not differ significantly from the other nonpulled treatments by 2012. Increasing knapweed biomass on nonpulled clopyralid plots, leading to increased seed fall (Story et al. 2001), is likely to produce an increase in density as well. Knapweed resurgence on nonpulled clopyralid and glyphosate treatments in our study is consistent with the results of Rice et al. (1997), who observed knapweed to increase to untreated levels by the sixth year after single herbicide treatments.

Burning Effects on Knapweed. There were no significant main or interaction effects related to the 2012 burning treatment on adult knapweed density, total biomass, or on juvenile knapweed density. Burning main effects were significant for seedling knapweed density in 2012 ( $\mathrm{P}=$ $0.046)$, however, with seedling density on burned plots $\left(1.8 \pm 0.6 \mathrm{~m}^{-2}\right.$, mean $\left.\pm \mathrm{SE}\right)$ being slightly greater than on unburned plots $\left(0.9 \pm 0.5 \mathrm{~m}^{-2}\right)$. We originally planned to burn in late April, but elected to burn in early April because an extended period of unseasonably warm weather in mid-March advanced plant phenology and shortened the spring fire window. Early spring burns, however, are less effective than mid- to late spring or summer burns for controlling spotted knapweed (Emery et al. 2003; Emery and Gross 2005; MacDonald et al. 2007). Although several studies have reported reduced spotted knapweed germination and emergence in response to burning (MacDonald et al. 2001, 2007; Vermeire and Rinella 2009), we detected slightly greater seedling establishment on burned plots. We observed mean fire temperatures less than $160 \mathrm{C}$, so the burn might not have been sufficiently hot or of sufficient duration to reduce knapweed seed germination. Under laboratory conditions, Abella and MacDonald (2000) did not observe a decrease in germination until knapweed seeds had been exposed to 200 C for 120 s. In contrast, Vermeire and Rinella (2009) reported reduced knapweed germination at temperatures ranging from 107 to $143 \mathrm{C}$ with fuel loads from 100 to $700 \mathrm{~g} \mathrm{~m}^{-2}$. Response to fire under field conditions is likely affected by a variety of factors, including fuel moisture and weather conditions (Vermeire and Rinella 2009). Neither of these were optimal in our study given the high relative humidity $(49 \%)$ and cool air temperature $(13.7 \mathrm{C})$ on the day of our burn. It seems unlikely that knapweed seed germination was increased by burning, because there is no evidence that low-intensity fires would increase germination in this species (Abella and MacDonald 2000; Vermeire and Rinella 2009). Low-intensity fires, however, can create disturbance that favors knapweed establishment (Sheley et al. 1998), which could increase the risk of knapweed resurgence on the nonpulled burned plots.

Hand-Pulling Effects on Knapweed. Adult knapweed densities did not differ significantly between pulled and nonpulled plots before the initial pulling treatment was applied in 2009 (Table 1). Based on annual counts in midJuly, the early July pulling reduced mean adult knapweed densities to $0.13 \pm 0.05$ plants $\mathrm{m}^{-2}$ (mean \pm SE) each year. Hand-pulling effects on adult knapweed densities became significant on the mowed treatment in 2010, on the glyphosate treatment in 2011, and on the clopyralid treatment in 2012 (Table 1). By 2012, mean adult knapweed densities on hand-pulled treatments had been reduced to $0.57 \pm 0.12 \mathrm{~m}^{-2}$ (mean $\pm \mathrm{SE}$ ), $5.8 \%$ of mean densities on the nonpulled treatments.

In 2009, differences in biomass between pulled and nonpulled treatments largely represented divergence related to the different biomass sampling times in early and midJuly (Table 2). From 2010 on, differences in biomass between pulled and nonpulled treatments increasingly reflected the reductions in adult knapweed densities produced by hand pulling. By 2012, adult knapweed biomass averaged across hand-pulled treatments was 7.1\% of nonpulled treatments.

Reductions in juvenile knapweed densities on handpulled treatments became significant from 2010 on for mowed plots, from 2011 on for glyphosate-treated plots, and in 2012 for clopyralid-treated plots (Table 4). Similarly, hand-pulling effects on seedling densities became pronounced in 2010 on mowed plots and 2011 on herbicide-treated plots (Table 3). Although severe drought (NDMC 2012) tended to reduce seedling densities on all treatments in 2012 compared to 2011, hand-pulling main effects were still significant. Hand-pulling effects on the knapweed seed bank took longer to detect, with mean seed bank density on the pulled treatments not becoming significantly reduced compared to either untreated areas at the study site or nonpulled treatments until 2012 (Table 5).

During the first year, hand pulling required substantial amounts of labor to clear heavily infested plots ( 4 to 6 person-hr per $25-\mathrm{m}^{2}$ plot), and the time and effort required would be prohibitive when treating extensive knapweed infestations (Duncan et al. 2011). As a follow-up to picloram treatment, Lutgen and Rillig (2004) reported that $4 \mathrm{yr}$ of hand pulling reduced spotted knapweed cover to $1 \%$, as compared to 0 to $6 \%$ with picloram alone. After $3 \mathrm{yr}$ 
Table 5. Knapweed seed bank density (mean \pm SE) at the Bass River Recreation Area, Ottawa County, Michigan, as affected by initial mowing and herbicide treatments or hand pulling.

\begin{tabular}{|c|c|c|c|c|c|}
\hline \multirow[b]{2}{*}{ Year } & \multirow[b]{2}{*}{$\begin{array}{l}\text { Hand-pulling } \\
\text { treatment }\end{array}$} & \multicolumn{3}{|c|}{ Initial mowing or herbicide treatment (MH) } & \multirow[b]{2}{*}{ Hand-pulling means } \\
\hline & & Mowing & $\begin{array}{l}\text { Mowing plus } \\
\text { clopyralid }\end{array}$ & $\begin{array}{l}\text { Mowing plus } \\
\text { glyphosate }\end{array}$ & \\
\hline & & & seeds ge & ted $m^{-2}$ & \\
\hline \multirow[t]{3}{*}{2009} & Nonpulled & $252 \pm 67$ & $142 \pm 44$ & $252 \pm 71$ & $215 \pm 36$ \\
\hline & Pulled & $267 \pm 87$ & $252 \pm 95$ & $283 \pm 57$ & $267 \pm 45$ \\
\hline & MH means & $259 \pm 53$ & $197 \pm 53$ & $267 \pm 44$ & $417 \pm 87^{\mathrm{a}}$ \\
\hline \multirow[t]{3}{*}{2010} & Nonpulled & $252 \pm 75$ & $94 \pm 31$ & $141 \pm 90$ & $162 \pm 41$ \\
\hline & Pulled & $126 \pm 34$ & $141 \pm 69$ & $63 \pm 34$ & $110 \pm 28$ \\
\hline & MH means & $189 \pm 43$ & $118 \pm 37$ & $102 \pm 48$ & $393 \pm 140^{\mathrm{a}}$ \\
\hline \multirow[t]{3}{*}{2011} & Nonpulled & $346 \pm 70 \mathrm{~m}^{\mathrm{b}}$ & $63 \pm 24 n^{b, c}$ & $487 \pm 153 \mathrm{~m}^{\mathrm{b}}$ & $299 \pm 66$ \\
\hline & Pulled & $220 \pm 123$ & $597 \pm 354$ & $126 \pm 58$ & $314 \pm 128$ \\
\hline & MH means & $283 \pm 70$ & $330 \pm 185$ & $307 \pm 92$ & $574 \pm 127^{\mathrm{a}, \mathrm{c}}$ \\
\hline \multirow[t]{3}{*}{2012} & Nonpulled & $1,006 \pm 756$ & $220 \pm 91$ & $346 \pm 85$ & $524 \pm 254 x^{b}$ \\
\hline & Pulled & $110 \pm 65^{\mathrm{c}}$ & $63 \pm 34^{\mathrm{c}}$ & $31 \pm 31^{\mathrm{c}}$ & $68 \pm 26 y^{b, c}$ \\
\hline & MH means & $558 \pm 384$ & $141 \pm 51$ & $189 \pm 60$ & $369 \pm 66^{a, c}$ \\
\hline
\end{tabular}

${ }^{a}$ Mean seed bank density in adjacent untreated knapweed-infested areas of the study site in bold.

${ }^{\mathrm{b}}$ Means followed by different letters differ significantly. Letters $\mathrm{m}$ and $\mathrm{n}$ compare mowing or herbicide means within a single year and hand-pulling treatment; and $\mathrm{x}$ and $\mathrm{y}$ compare hand-pulling main effects means within a single year. If interaction effects were not significant, lettering is only shown for significant main effects.

'Within a single year, untreated mean also differs significantly from treatment means.

of hand pulling (2009 to 2011), we observed substantial reductions in density and biomass of adult knapweed when combined with single applications of mowing or herbicides. Lutgen and Rillig (2004) reported that hand pulling to remove tops and the upper 2.5 to $5 \mathrm{~cm}$ of root did not reduce knapweed cover below that of an untreated control. In comparison, we found that hand pulling using a weeding tool to remove entire tap roots significantly reduced knapweed density and biomass on the mowed-only treatment, where substantial numbers $\left(44 \pm 7 \mathrm{~m}^{-2}\right)$ of adult knapweed needed to be removed during the first year of treatment. Thus, careful weeding to remove entire plants might be needed if hand pulling is used as a means of control. Skurski et al. (2013) hand pulled knapweed when soils were wet to facilitate removal of entire plants, reducing knapweed cover from $10 \%$ to less than $2 \%$ after 1 yr. Because they did not continue hand pulling in subsequent years, knapweed cover began to increase again. To be effective, hand pulling needs to be continued for multiple years until the population of adults, juveniles, seedlings, and the seed bank is controlled.

We found the only treatment combinations that ultimately reduced the knapweed seed bank included hand pulling as a follow-up measure to initial mowing and herbicide treatments. Mean knapweed seed bank densities in untreated areas in the vicinity of our study plots $\left(438 \pm 46 \mathrm{~m}^{-2}\right.$, mean $\left.\pm \mathrm{SE}\right)$ were similar to estimated seed bank densities on moderately infested remnant prairies in Michigan (300 to $700 \mathrm{~m}^{-2}$, assuming $50 \%$ survival of annual seed fall in the seed bank for $1 \mathrm{yr}$; Emery and Gross 2005). Although data on the seed bank densities of knapweed-infested sites in the Midwest are limited, the densities we observed also were similar to those in moderately infested areas of western Montana $\left(281 \pm 106 \mathrm{~m}^{-2}\right.$; Story et al. 2008). We observed a reduction in the knapweed seed bank to an average of $68 \pm 26 \mathrm{~m}^{-2}$ after $3 \mathrm{yr}$ of hand pulling, approaching seed bank densities of 32 to $42 \mathrm{~m}^{-2}$ reported by Davis et al. (1993) after $7 \mathrm{yr}$ of suppression of seed production using annual herbicide treatments. The reduced knapweed seed bank density observed in our study also was similar to the seed bank density of $52 \pm 17 \mathrm{~m}^{-2}$ observed after $6 \mathrm{yr}$ of competition with native grasses and $3 \mathrm{yr}$ of annual burning in a previous study in an adjacent area of our study site (MacDonald et al. 2007). The mean seed bank density on hand-pulled plots was below the approximate threshold of 160 seeds $\mathrm{m}^{-2}$ where knapweed populations remain low when seed production has been consistently reduced by biological control (Story et al. 2008), suggesting that hand pulling provides an effective means of reducing seed bank densities on infested sites. Without continued suppression of seed production, seed bank densities likely will return to the greater than $400 \mathrm{~m}^{-2}$ found on untreated areas in this study, emphasizing the need for multiple years of hand pulling to 
control knapweed on an infested site. Although published data on hand pulling of spotted knapweed are limited, previous reviews have stated that persistent hand pulling can control spotted knapweed (e.g., Abella 2001; Duncan et al. 2011; Sheley et al. 1998). Our study provides experimental evidence that strongly supports this conclusion.

\section{Acknowledgments}

The GVSU Student Summer Scholars Program, WaddellTreanor Native Plants Endowment, and Biology MS program provided funding for the study; Glenn Palmgren, Charles Ehrlich, and Patrick Whalen of the Michigan Department of Natural Resources granted permission to use the Bass River Recreation Area; Leo Evans and Paul Rogers of the Michigan Department of Natural Resources conducted the prescribed burn; Diane Laughlin and Star Santiago helped with laboratory and greenhouse logistics; Jennifer Burmeister, Korie Hamming, and Wendal Kane assisted with the seed bank study; David Hillger of Dow Agrosciences provided an experimental sample of Transline herbicide used in this study; and the Associate Editor and two anonymous reviewers provided perceptive and helpful comments on the manuscript. We thank all of these individuals and entities for their generous assistance.

\section{Literature Cited}

Abella, S. R. 2001. Effectiveness of different management strategies for controlling spotted knapweed in remnant and restored prairies. Ecol. Restor. 19:117-118.

Abella, S. R. and N. W. MacDonald. 2000. Intense burns may reduce spotted knapweed germination. Ecol. Restor. 18:203-205.

Anderson, M. J. 2005. PERMANOVA: A FORTRAN Computer Program for Permutational Multivariate Analysis of Variance. Auckland, New Zealand: Department of Statistics, University of Auckland. 24 p.

Brown, M. L., C. A. Duncan, and M. B. Halstvedt. 1999. Spotted knapweed management with integrated methods. Proc. West. Soc. Weed Sci. 52:68-70.

Carey, E. V., M. J. Marler, and R. M. Callaway. 2004. Mycorrhizae transfer carbon from a native grass to an invasive weed: evidence from stable isotopes and physiology. Plant Ecol. 172:133-141.

Carpinelli, M. F., R. L. Sheley, and B. D. Maxwell. 2004. Revegetating weed-infested rangeland with niche-differentiated desirable species. J. Range Manag. 57:97-105.

Crone, E. E., M. Marler, and D. E. Pearson. 2009. Non-target effects of broadleaf herbicide on a native perennial forb: a demographic framework for assessing and minimizing impacts. J. Appl. Ecol. 46: 673-682.

Davis, E. S., P. K. Fay, T. K. Chicoine, and C. A. Lacey. 1993. Persistence of spotted knapweed (Centaurea maculosa) seed in soil. Weed Sci. 41:57-61.

DiTomaso, J. M. 2000. Invasive weeds in rangelands: species, impacts, and management. Weed Sci. 48:255-265.

Duncan, C., J. Story, and R. Sheley. 2011. Biology, ecology, and management of Montana knapweeds. Extension Bulletin EB0204. Bozeman, MT: Montana State University Extension. 19 p.

Emery, S. M. and K. L. Gross. 2005. Effects of timing of prescribed fire on the demography of an invasive plant, spotted knapweed Centaurea maculosa. J. Appl. Ecol. 42:60-69.
Emery, S. M., K. L. Gross, and K. N. Suding. 2003. Summer burns best for controlling spotted knapweed in prairie restoration experiment (Michigan). Ecol. Restor. 21:137-138.

Hastings, M. S. and J. M. DiTomaso. 1996. Fire controls yellow star thistle in California grasslands. Restor. Manag. Notes 14:124-128.

Herron, G. J., R. L. Sheley, B. D. Maxwell, and J. S. Jacobsen. 2001. Influence of nutrient availability on the interaction between spotted knapweed and bluebunch wheatgrass. Restor. Ecol. 9:326-331.

Hierro, J. L. and R. M. Callaway. 2003. Allelopathy and exotic plant invasion. Plant Soil 256:29-39.

Kennard, D. K., K. W. Outcalt, D. Jones, and J. J. O'Brien. 2005. Comparing techniques for estimating flame temperature of prescribed fires. Fire Ecol. 1:75-84.

Kennett, G. A., J. R. Lacey, C. A. Butt, K. M. Olson-Rutz, and M. R. Haferkamp. 1992. Effects of defoliation, shading and competition on spotted knapweed and bluebunch wheatgrass. J. Range Manag. 45: 363-369.

Klute, A., ed. 1986. Methods of Soil Analysis. Part 1: Physical and Mineralogical Properties. 2nd ed. Madison, WI: American Society of Agronomy and Soil Science Society of America. 1188 p.

Lutgen, E. R. and M. C. Rillig. 2004. Influence of spotted knapweed (Centaurea maculosa) management treatments on arbuscular mycorrhizae and soil aggregation. Weed Sci. 52:172-177.

MacDonald, N. W., P. J. Bosscher, C. A. Mieczkowski, E. M. Sauter, and B. J. Tinsley. 2001. Pre- and post-germination burning reduces establishment of spotted knapweed seedlings (Michigan). Ecol. Restor. 19:262-263.

MacDonald, N. W., M. T. Koetje, and B. J. Perry. 2003. Native warmseason grass establishment on spotted knapweed-infested gravel mine spoils. J. Soil Water Conserv. 58:243-250.

MacDonald, N. W., B. T. Scull, and S. R. Abella. 2007. Mid-spring burning reduces spotted knapweed and increases native grasses during a Michigan experimental grassland establishment. Restor. Ecol. 15: $118-128$.

Maron, J. and M. Marler. 2007. Native plant diversity resists invasion at both low and high resource levels. Ecology 88:2651-2661.

McArdle, B. H. and M. J. Anderson. 2001. Fitting multivariate models to community data: a comment on distance-based redundancy analysis. Ecology 82:290-297.

[NCDC] National Climatic Data Center. 2009. Local Climatological Data, Annual Summary with Comparative Data for Muskegon, Michigan (KMKG). Monthly Precipitation Data for 1980-2009 Obtained from the National Climatic Data Center, Asheville, NC. http://www.ncdc.noaa.gov/. Accessed October 12, 2010.

[NDMC] National Drought Mitigation Center. 2012. U. S. Drought Monitor, Michigan, July 24, 2012. National Drought Mitigation Center, University of Nebraska, Lincoln. http://droughtmonitor.unl. edu/. Accessed July 31, 2012.

Packard, S. and C. F. Mutel, eds. 1997. The Tallgrass Restoration Handbook. Covel, CA: Island Press. 463 p.

Page, A. L., R. H. Miller, and D. R. Keeney, eds. 1982. Methods of Soil Analysis. Part 2: Chemical and Microbiological Properties. 2nd ed. Madison, WI: American Society of Agronomy and Soil Science Society of America. 1159 p.

Rice, P. M., J. C. Toney, D. J. Bedunah, and C. E. Carlson. 1997. Plant community diversity and growth form responses to herbicide applications for control of Centaurea maculosa. J. Appl. Ecol. 34: 1397-1412.

Rinella, M. J., J. S. Jacobs, R. L. Sheley, and J. J. Borkowski. 2001. Spotted knapweed response to season and frequency of mowing. J. Range Manag. 54:52-56.

Rinella, M. J., B. D. Maxwell, P. K. Fay, T. Weaver, and R. L. Sheley. 2009. Control effort exacerbates invasive species problem. Ecol. Appl. 19:155-162. 
Rinella, M. J., M. L. Pokorny, and R. Rekaya. 2007. Grassland invader responses to realistic changes in native species richness. Ecol. Appl. 17:1824-1831.

Schirman, R. 1981. Seed production and spring seedling establishment of diffuse and spotted knapweed. J. Range Manag. 34:45-47.

Sheley, R. S., C. A. Duncan, M. B. Halstvedt, and J. S. Jacobs. 2000. Spotted knapweed and grass response to herbicide treatments. J. Range Manag. 53:176-182.

Sheley, R. L. and M. L. Half. 2006. Enhancing native forb establishment and persistence using a rich seed mixture. Restor. Ecol. 14:627-635.

Sheley, R. L., J. S. Jacobs, and M. F. Carpinelli. 1998. Distribution, biology, and management of diffuse knapweed (Centaurea diffusa) and spotted knapweed (Centaurea maculosa). Weed Technol. 12: 353-362.

Sheley, R. L., J. S. Jacobs, and D. E. Lucas. 2001. Revegetating spotted knapweed infested rangeland in a single entry. J. Range Manag. 54: $144-151$.

Skurski, T. C., B. D. Maxwell, and L. J. Rew. 2013. Ecological tradeoffs in non-native plant management. Biol. Conserv. 159:292-302.

Steel, R.G.D. and J. H. Torrie. 1980. Principles and Procedures of Statistics. 2nd edition. New York: McGraw-Hill Book Company. 633 p.
Story, J. M., L. Smith, J. G. Corn, and L. J. White. 2008. Influence of seed head-attacking biological control agents on spotted knapweed reproductive potential in western Montana over a 30-year period. Environ. Entomol. 37(2):510-519.

Story, J. M., L. Smith, and W. R. Good. 2001. Relationship among growth attributes of spotted knapweed (Centaurea maculosa) in western Montana. Weed Technol. 15:750-761.

Tyser, R. W., J. M. Asebrook, R. W. Potter, and L. L. Kurth. 1998. Roadside revegetation in Glacier National Park: effects of herbicide and seeding treatments. Restor. Ecol. 6:197-206.

Vermeire, L. T. and M. J. Rinella. 2009. Fire alters emergence of invasive plant species from soil surface-deposited seeds. Weed Sci. 57: 304-310.

Wally, A. L., E. S. Menges, and C. W. Weekley. 2006. Comparison of three devices for estimating fire temperatures in ecological studies. Appl. Veg. Sci. 9:97-108.

Watson, A. K. and A. J. Renney. 1974. The biology of Canadian weeds. 6. Centaurea diffusa and C. maculosa. Can. J. Plant Sci. 54:687-701. Wilkinson, L. 1989. SYSTAT: The System for Statistics. Version 4. Evanston, IL: SYSTAT Inc. 822 p.

Received August 6, 2012, and approved May 21, 2013. 